В-третьих, чем больше будет мудрых людей в обществе, тем вероятнее появление мудрого времени, а следовательно, и утверждение новых условий, лежащих в основе и иной, по-настоящему человеческой жизни.

Таким образом, знания о типологии образа мудреца на основе временных показателей затрагивает всех и заставляет задуматься каждого человека.

$$
* * *
$$

1. Бейль П. Исторический и критический словарь: В 2 т. Пер. с фр. М., 1968. Т. 2.

2. Бердяев Н.А. О рабстве и свободе человека (Опыты персоналистичес-кой философии). Париж, 1939.

3. Грималь П. Сенека, или Совесть Империи. М., 2003.

4. Камю А. Миф о Сизифе; Бунтарь / Пер. с фр. Мн., 2000.

5. Кант И. Приложения к «Наблюдениям над чувством прекрасного и возвышенного» // Соч.: В 6 т. Т. 2. M., 1964.

6. Конфуций. Уроки мудрости: Соч. М., Харьков, 2003.

7. Назаров В.Н. Нравственная мудрость как творчество жизни // Филос. науки. 1991. № 11. С. 51-64.

8. Назаров В.Н. Феноменология мудрости: Образы мудреца в истории культуры. Тула, 1993.

9. Нискер В. Безумная мудрость. СПб., 2000.

10. Ницше Ф. О пользе и вреде истории для жизни. Сумерки кумиров, или как философствовать молотом. О философах. Мн., М., 2000.

11. Симененко И.И. Мудрость Конфуция // Милосердие в учении Конфуция. М., 1989.

12. Фролов И.Т. О человеке и гуманизме: Работы разных лет. М., 1989.

\title{
Черниговских И.В. \\ К проблеме взаимодействия социальных подсистем: детерминирование и доминирование
}

Воронежский государственный университет инженерных технологий

(Россия, Воронеж)

doi:10.18411/spc-10-01-2018-03

idsp: 000001:spc-10-01-2018-03

Рассматривая общество как систему, мы неизбежно сталкиваемся с проблемой выделения соответствующих структурных элементов. Одним из вариантов структурирования общества является выделение сфер его жизни. В данном случае понятием «сфера» фиксируется некоторая идентичность, некоторое единообразие структурных элементов общественного организма. Тем самым создаются новые возможности понимания и структуры общества, состоящего не просто из разнокачественных, неповторимо своеобразных компонентов, но из общих, единых, в каком-то смысле одинаковых. При этом следует подчеркнуть, что пока еще нет общепринятого научного, теоретически развернутого определения сферы общественной жизни. Конечно, это не означает, что вообще нет общности в понимании сферы общественной жизни. Все исследователи под сферой общественной жизни понимают элемент общества, его часть, объективно существующую, как-то структурно оформленную, связанную с другими сферами, с обществом в целом.

Нам представляется, что использование в данном контексте понятия «сфера» не совсем удачно. Само слово «сфера», как известно, означает в геометрии «замкнутую поверхность, все точки которой одинаково удалены от центра». В данном смысле оно невольно наводит на мысль об обособленности этих частей общества, хотя они неразрывно связаны. Поэтому, наиболее подходящим для целей нашего исследования мы считает понятие «подсистема».

Социальная система, как любая сложная живая система, призвана, прежде всего, обеспечить свое существование, т. е. обеспечить воспроизводства своего основного элемента - субъекта. Для достижения этого она должна решить следующие задачи: 
1) организовать производство необходимых средств, которые призваны удовлетворять потребности составляющих ее субъектов. При этом эти средства должны удовлетворять как потребности в материальных предметах, так и в информационносимволических образованиях. Это в свою очередь предполагает наличие двух видов производства: материального и информационно-символического;

2) организовать распределение этих средств и тем самым обеспечить оптимальное функционирование и развитие системы;

3) обеспечить потребление произведенных средства и тем самым воспроизводство своих субъектов.

Таким образом, в качестве основных подсистем общества можно выделить: 1) материально-производственную; 2) информационно-символическую; 3) подсистему управления общественными процессами; 4) собственно социальную.

Каждая подсистема имеет свою функцию. Так, материально-производственная подсистема призвана создавать определенные материальные блага, необходимые для удовлетворения потребностей людей. С момента появления металлических денег она принимает финансово-экономических характер. Сходную функцию выполняет и информационно-символическая подсистема. Она обеспечивает получение и накопление информации, необходимые для удовлетворения потребностей людей, и закрепляет ее в символической форме. С момента появления классов и государства как аппарата власти эта подсистема принимает идеологический характер, т. е. начинает отражать социальную действительность с точки зрения интересов определённых групп или классов, стремящихся сохранить существующий порядок вещей.

Подсистема управления общественными процессами отвечает за организацию распределения того, что было создано в материально-производственной и информационно-символической подсистемах для достижение оптимального функционирования и развития общества. С момента появления классов и государства как аппарата власти она принимает характер политического управления обществом. Субъектом управления начинает выступать определенная группа лиц, которая вырабатывает общие для всего государства цели, с которыми, так или иначе, согласовываются все остальные более частные цели отдельных сфер и деятельности индивидов в обществе.

В социальной подсистеме происходит потребление того, что создается в материально-производственной и информационно-символической подсистемах. Это потребление вместе с тем является и воспроизводством человека как природного, социального и культурного существа.

Отношения между подсистемами выстраиваются на основе детерминирования и доминирования.

Начиная с XVIII в. в социальных науках господствующим становится положение, что основой общества, детерминирующей все остальные ее подсистемы, является материально-производственная. Но, одновременно с этим, детерминирующая роль этой подсистемы стала выдаваться за доминирующую.

С начала XX в., благодаря успехам в изучении традиционных культур, доминирующая роль материально-производственной подсистемы начинает подвергаться сомнению. Исследования Б. Малиновского «Аргонавты западной части Тихого океана» (1922), М. Мосса «Очерк о даре» (1925) и др. показали, что в первобытных обществах трудно отделить экономику от других сфер. Экономические процессы опосредованы здесь отношениями родства, пола, возраста, разнообразными ритуалами, верованиями и проч. Однако, то же самое можно сказать и про политические процессы. В силу синкретичности первобытного общества экономические, политические, информационно-символические и социальные процессы 
тесно связаны между собой. Но и в данной ситуации можно говорить об определенном доминировании социальных и информационно-символических процессов.

Дальнейшие исследования показали, что материально-производственная подсистема не является доминирующей и в послепервобытных государственных сельскохозяйственных образованиях. Доминирующую роль эта сфера начинает приобретать только в Западной Европе, в так называемый «новый» период ее истории, т. е. с формированием капитализма [4].

Результаты этих исследований были обобщены американским и канадским экономистом, антропологом, социологом и политическим философом венгерского происхождения К. Поланьи, который предложил для анализа этой ситуации две модели положения экономики по отношению к обществу: «внедренного» и «выделившегося (автономного)» [2, с. 121].

Таким образом, нельзя говорить о доминировании какой-то одной подсистемы на протяжении всей истории человечества. История человечества - это история борьбы за доминирование между разными подсистемами.

Само стремление к доминированию связано с тем, что каждая из подсистем имеет свои средства (инструментальные по отношению к системе как целому) для реализации своей системной функции. Так, например, для материальнопроизводственной подсистемы (в ее финансово-экономическом варианте) таким средством является получение прибыли, для подсистемы управления общественными процессами (в ее политическом варианте) - власть. При этом подсистемы стремятся превратить эти средства в самостоятельные цели, первоначально в собственных рамках, а затем и всей социальной системы в целом. В результате, каждая подсистема стремится стать доминирующей и навязать свое средство, превращенное в цель, всей системе в целом. Однако это стремление наталкивается на противодействие других подсистем, преследующих ту же цель. Кроме того, на этот процесс оказывает влияние то обстоятельство, что «осознание» своего интереса каждой подсистемой происходит в разные исторические периоды. Раньше всех «осознают» свои интересы подсистемы управления общественными процессами и информационно-символическая. Это происходит в эпоху разложения первобытнообщинного строя и формирования первых государственных образований. Именно между этими подсистема первоначально разворачивается борьба за доминирование (образно говоря между «жрецом» и «царем») $[5$, c. 8$]$.

B XV-XVII вв. в Западной Европе проходят процессы, которые приводят к победе подсистемы управления общественными процессами в этом противостоянии и подчинении ей информационно-символической подсистемы. Одним из проявлений этого стало Аугсбургское соглашение 1555 г., согласно которому каждый правитель сам определял вероисповедание в своих владениях. Позднее это положение трансформировалось в принцип cujus regio, eius religio (лат. «чья страна, того и вера»).

Однако ослабление влияния информационно-символической подсистемы приводит к активизации материально-производственной: ослабление роли религии, которая определяла информационно-символическую подсистему в Средние века, привело к постепенному замещению духовных, «небесных» целей и ценностей материальными, земными. Можно привести известные афоризмы из Нового Завета, отражающие отношение к материальному богатству в христианской системе ценностей: «как трудно имеющим богатство войти в Царствие Божие! ибо удобнее верблюду пройти сквозь игольные уши, нежели богатому войти в Царствие Божие». (Лук.18:16-27); «Не собирайте себе сокровищ на земле, где моль и ржа истребляют и где воры подкапывают и крадут, но собирайте себе сокровища на небе, где ни моль, ни ржа не истребляют и где воры не подкапывают и не крадут, ибо где сокровище ваше, там будет и сердце ваше» (Мат. 6: 19-21). 
В реальной жизни это отношение к богатству проявилось в осуждении церковью ростовщичества в европейском средневековье. Согласно христианской картине мира время принадлежит Богу, а не человеку. Ростовщическая деятельность представляет собой посягательство на время, а значит является прегрешением против Творца. Логика рассуждения здесь такова. Любой другой грех нуждается в отдыхе и не совершается непрерывно. Убийца не покушается непрестанно на жизнь других людей; прелюбодей когда-нибудь да отдыхает; вор не крадет не покладая рук; никто не в состоянии постоянно впадать в грех клятвопреступления. Но грех ростовщика отличается постоянством. В будни и в праздники, равно в те часы, когда ростовщик бодрствует или когда он спит, его деньги, которые он отдал под проценты, продолжают непрерывно и неустанно трудиться на него и приносить ему прибыль. Его «волы», т. е. деньги, «пашут, не уставая». Следовательно, ростовщик торгует временем, которое ему не принадлежит. Иными словами, он покушается на Божьи дары - на день и ночь. А потому он должен быть лишен вечного дня, т. е. загробного спасения, и брошен во мрак вечной ночи, т. е. в ад. По мнению А. Я. Гуревича, осуждение ростовщичества вызывалось не одними доктринальными причинами, оно было обусловлено и общественным мнением. В результате этого конфликта, с одной стороны, с церковной доктриной, а, с другой стороны, с настроениями большинства населения, известны случаи, когда люди, накопившие богатства неправомерными средствами, на пороге смерти или в ее преддверии отказывались от своих неправедно нажитых богатств, возвращали деньги ограбленным им лицам, жертвовали беднякам и сиротам, оставляли средства на заупокойные мессы и молитвы [1; 236].

В результате снятия религиозного запрета с получения процента, оправдание использование богатства (хотя бы и заработанного честным трудом) в личных, а не в общественных целях (не в целях служения) открывало дорогу для усиления роли и значения материально-производственной подсистемы (в ее финансово-экономическом варианте).

Кроме того, формирующиеся государства-нации были заинтересованы в развитии своей экономической мощи, что обеспечивало им, прежде всего, военное превосходство. В результате политические элиты сами создавали себе конкурента в лице формирующейся экономической элиты. Результат этого процесса ярко продемонстрировали буржуазные революции XVII-XVIII вв., в которых новые экономические элиты в лице буржуазии свергли старую политическую элиту в лице королей и придворных. Это был грандиозный успех в заявке на доминирование материально-производственной подсистемы. Таким образом, начиная с этого времени, разворачивается борьба за доминирование между материально-производственной подсистемой и подсистемой управления общественными процессами. Явным успехом материально-производственной подсистемы в этой борьбе является развал социалистической системы, т. к. СССР представлял собой общество с явным доминированием подсистемы управления общественными процессами. Сам этот развал стал следствием сознательно проводимого курса по освобождению экономики из-под социального и государственного контроля, превращение его в бесконтрольную силу, который французский социолог П. Бурдье связывает с глобализацией. Немецкие экономисты Р. Хикель и Ф. Штрикштрок, как, впрочем, и многие другие, подчёркивают: пока существовал СССР, глобализация не просто тормозилась, а не могла реализоваться как таковая. Однако, по мнению А. И. Фурсова, сама глобализация создает фундамент для новой, посткапиталистической системы: «это одновременно гибель капитализма и передел с прицелом на посткапиталистическое будущее» [3].

Если исходить из того, что главной целью существования общества является воспроизводство своего основного элемента, т. е. субъекта, а воспроизводство человека как природного, социального и культурного существа - это функция собственно 
социальной подсистемы, то логично предположить, что доминирующей должны быть именно эта подсистема. Однако данная организация взаимодействия является идеальной моделью, примеры воплощения которой в реальной истории почти исключительны.

$$
* * *
$$

1. Гуревич А. Я. Исторический синтез и Школа «Анналов». - Москва, Санкт-Петербург : Центр гуманитарных инициатив, Университетская книга, 2014. - 432 с.

2. Поланьи К. Аристотель открывает экономику // Поланьи К. Избранные работы. - М. : Издательский дом «Территория будущего», 2010. - С. 117-152.

3. Фурсов А. И. Глобализация против планеты. Феномен БРИКС // Завтра [сайт]. - URL: http://zavtra.ru/blogs/fenomen_briks (дата обращения 08.12.2018 г.)

4. Черниговских И. В. Изменение места и роли экономики в процессе развития общества // Духовная жизнь общества и человека : история и современность : международный сб. научн. тр. - Воронеж : ВГУИТ, 2013. - Вып. 6. - С. 154-164.

5. Черниговских И. В. Основные подсистемы общества: борьба за доминирование // Current issues of modern socio-political phenomena: theoretical and methodological and applied aspects : materials of the IV international scientific conference on March 13-14, 2016. - Prague : Vědecko vydavatelské centrum «Sociosféra-CZ», 2016. - P. 6-9. 